\title{
The Local Government Budget (APBD) and Its Inefficiency in the City of Malang, Indonesia
}

\author{
Ya'qud A. Gudban, Candra F. Ananda, Susilo, and Setyo T. Wahyudi \\ Department of Economics, Brawijaya University, Indonesia
}

\begin{abstract}
This article describes the process of making the Local Government Budget (APBD) in Indonesia generally and Malang City particularly. The process will be viewed from the perspective of principal-agent relationship, in which the legislature is placed as principal while the executive as an agent. When APBD is going to be fixed as the regulation, there may be debates and negotiations between the executive and the legislature. The debate and negotiation go on until the end of the process of making APBD. It relates to the interests of legislators towards the base of their constituents and relates to the inconsistecy between what is planned and what is going to be financed.

One of the result of this situation is the phenomenon of ghost budget (anggaran siluman), that is the budget that suddenly appears in APBD without going through the right procedure. The ghost budget can be understood as the unplanned budget, and it is the result of hidden compromises between the legislature and the executive. Because this budget is not well planned, it usually can not be executed, and then it becomes the unspent budget (SiLPA). This paper recommends to create more transparent system in the process of making APBD.
\end{abstract}

Keywords: legislature, executive, local government budget (APBD), ghost budget, unspent budget (SiLPA)

\section{INTRODUCTION}

APBD (Anggaran Pendapatan dan Belanja Daerah) or the Local Government Budget is a political process. It is the instrument of accountability in the management of public funds and the implementation of programs funded with public funds (Mardiasmo, 2002). Simply put, the Local Government Budget describes the local government's financial condition containing information on revenues, expenditures, and activities. In Indonesia, during the era of New Order (Orde Baru), the making of APBD was done by the top-down system, where plans and the budget amount were set by superiors, while subordinates only did what had been budgeted. Now, in the era of Reformation (Reformasi), Indonesia applies the principle of participation in the making of APBD since the issuance of Government Regulation No. 105 of year 2000 on th eLocal Financial Management and Accountability which then has been replaced by Government Regulation No. 58 of year 2005.

There are two interesting phenomena in the process of making APBD in Indonesia. Firstly, the legislature (rather than the executive) has sufficient powers in influencing the creation of APBD. The role of the local legislature is played by DPRD (Dewan Perwakilan Rakyat Daerah, the Local House of Representatives) and the role of the local executive is performed by a governor (gubernur) for a province, or a mayor (walikota) for a city (kota), or a regent (bupati) for regency (kabupaten). The executive is considered to be inferior to the legislature, and sometimes the executive is difficult to reject 'recommendations' from the legislature in the allocation of funding sources, and this in turn may distort what has been planned by the executive. It is important to know that Indonesia has 34 provinces and one of them is the Province of Jawa Timur which is governed by the Governor. The Province of Jawa Timur is divided into 38 regions: 29 regions as regencies (kabupaten) plus 9 regions as cities (kota). The city is governed by a mayor (walikota), and the regency is governed by a regent (bupati). Secondly, the executive is more likely to engage in corruption, because what has been planned by the executive and legislature will be executed by the executive itself. Corrupt behavior is associated with opportunities for personal benefit in all levels of public budgeting process, from the planning to the payment of public services provided by the executive (Abdullah 2004).

The purpose of this article is to describe the process of making the Local Government Budget (APBD) in Indonesia generally and Malang City particularly. The process will be viewed from the perspective of agency relationship, in which the legislature is placed as principal while the executive as an agent. It will focus on the government budgeting in the City of Malang, in the Province of Jawa Timur, Indonesia.

\section{THE THEORY OF AGENCY}

The relationship between the legislature and the executive can be regarded as an agency relationship, arising from a contract between people and their representatives in the legislature, and the legislature asks the 
The Local Government Budget (APBD) and Its Inefficiency in the City of Malang, Indonesia

executive (along with its bureaucracy) to provide goods and services for the benefit of the people (Maug 2002). To supervise the behavior of the executive as well as to align the people's interests with the executive, the legislature requires the executive to account for the use of the budget through periodic financial reporting mechanisms. Through their representatives in the legislature, the people can measure and assess the performance of the executive, and to oversee the extent to which the executive has acted to improve the welfare of the people. In short, agency theory or principal-agent theory is to analyze the contractual relationship between two parties: one is the principal and the other is the agent. The principal makes a contract, either implicitly or explicitly, with the agent in the hope that the agent will perform tasks as desired by the principal. However, the theory predicts that the agent may behave opportunistically toward the principal.

According to Bergman and Lane (1990), the principal-agent framework relates to information asymmetry: the agent has more information about its actual performance, its hidden motivation, and its goal. The principal, however, must exert efforts to monitor the performance of the agent and determine the structure of incentives for the agent. Asymmetry of information between the legislature and the executive offers the occurrence of opportunistic behavior in the process of planning as well as implementing public sector budget. According to Strom (2000), the principal-agent relationship in public sector budgeting can occur at various levels, among which are (1) voters and legislators, (2) legislators and executives, (3) mayors/regents and their bureaucratic apparatus, and (4) the treasurer and budget users. Gilardi (2001) notices these relationships as the chain of delegation.

\section{THE PROCESS OF MAKING APBD}

The process of making APBD (See Table 1) begins from RKPD (Rencana Kerja Pemerintah Daerah, the Local Government Work Plan), that is the documents of the work plan of the executive for a period of one year (step 1). RKPD is developed to ensure the relevance and the consistency between planning, budgeting, implementation and monitoring. RKPD mainly contains the measurable work plan that will implemented directly by the government and/or will be pursued by encouraging community participation. RKPD is set by the regulation of the mayor/regent as the head of the executive. Then, TAPD (Tim Anggaran Pemerintah Daerah, the Team of Local Government Budgeting) prepares KUA-PPAS and hands it over to the mayor/regent (step 2). KUA (Kebijakan Umum Anggaran, the Budget Policy) is the documents that describe the condition of local macroeconomy, the assumptions behind APBD, the policy of local incomes, local spending, local funding and strategies to achieve the targets of local development.

While PPAS (Prioritas dan Plafon Anggaran Sementara, the Budget Limits and Priorities) contains programs based on the duties and functions of every SKPD (Satuan Kerja Pemerintah Daerah, the Work Unit of the Local Government) such as the department of local education, the department of construction, the department of health, the department of local revenue, and so on. KUA-PPAS is submitted to local parliament (DPRD) as the legislature (step 3) to be discussed and agreed together with the executive (step 4). The mayor/regent then issues a circular letter, commanding every SKPD (the Work Unit of the Local Government) to prepare RKA-SKPD (Rencana Kerja dan Anggaran SKPD, the Work Plan and Budget of SKPD). Every SKPD is asked to prepare documents containing the planning of programs and activities and the necessary budget to implement them (step 5). RKA-SKPD is discussed within the executive, and it becomes the embryo of the of APBD (step 6). The mayor/regent submits the draft of ABPD to the legislature (step 7) to be discussed with the executive, they must agree with the draft (step 8), then the draft of APBD is to submitted to the Governor of the Province of Jawa Timur for evaluation (step 9), and finally the draft is set to be the local regulation or the final APBD (step 10).

\section{APBD AND THE GHOST BUDGET}

Indonesia adheres to public sector budgeting (APBD) based on performance. The performance-based budgeting explains the link between the allocation of resources to the achievement of measurable goals. It has been implemented in Indonesia under the Government Regulation (Peraturan Pemerintah) Number 105 of year 2000. The APBD is expected to encourage the participation of stakeholders in order to achieve the desired economic growth.The relationship between APBD based on performance and local economic growth in the City of Malang does not show satisfactory results. Here, APBD can be understood as government expenditure, which is together with private consumption and private investment, will contribute to local economic growth. In the City of Malang, APBD does not firmly encourage the economic growth of Malang City (see Figure 2). Figure 2 describes that the magnitude of government expenditure (APBD) of Malang City has not been able to boost economic growth. This can be seen in 2013 and 2014 where the economic growth has decreased at a time when government expenditure increases $22 \%$ in 2013.

Table 1 The Process of Making APBD

\begin{tabular}{|c|c|c|c|}
\hline No. & \multicolumn{1}{|c|}{ Activities } & Time Limits & Duration \\
\hline 1 & The creation of RKPD (Rencana Kerja Pemerintah Daerah, & The last May & \\
\hline
\end{tabular}


The Local Government Budget (APBD) and Its Inefficiency in the City of Malang, Indonesia

\begin{tabular}{|c|c|c|c|}
\hline & "Local Government Work Plan) & & \\
\hline 2 & $\begin{array}{l}\text { The submission of KUA (Kebijakan Umum Anggaran, the } \\
\text { Budget Policy) and PPAS (Prioritas dan Plafon Anggaran } \\
\text { Sementara, the Budget Limits and Priorities) from the head of } \\
\text { TAPD (Tim Anggaran Pemerintah Daerah, the Team of Local } \\
\text { Government Budgeting) to the mayor/regent. }\end{array}$ & Mid of June & One week \\
\hline 3 & $\begin{array}{l}\text { The submission of KUA from the mayor/regent to DPRD } \\
\text { (Dewan Perwakilan Rakyat Daerah, the Regional House of } \\
\text { Representatives) }\end{array}$ & The last June & six weeks \\
\hline 4 & KUA-PPAS must be agreed by the mayor/regent and DPRD & The last July & \\
\hline 5 & $\begin{array}{l}\text { The circular letter on guidelines of RKA-SKPD (RKA stands } \\
\text { for Rencana Kerja dan Anggaran SKPD, the Work Plan and } \\
\text { Budget, while SKPD stands for Satuan Kerja Pemerintah } \\
\text { Daerah, the Work Unit of the Local Government) }\end{array}$ & Early August & one week \\
\hline 6 & $\begin{array}{l}\text { The preparation and discussion of RKA-SKPD and the draft of } \\
\text { APBD (Anggaran Pendapatan dan Belanja Daerah, the } \\
\text { Regional Government Budget) }\end{array}$ & $\begin{array}{l}\text { Early August } \\
\text { until the last } \\
\text { Sept. }\end{array}$ & 7 weeks \\
\hline 7 & The submission of the draft of APBD to DPRD & $\begin{array}{l}\text { The first week } \\
\text { of October }\end{array}$ & 2 months \\
\hline 8 & The agreement on the draft of APBD & $\begin{array}{l}\text { one month } \\
\text { (max) before } \\
\text { fiscal year }\end{array}$ & \\
\hline 9 & The draft to be evaluated by the Ministry of Internal Affairs & $\begin{array}{l}15 \text { working } \\
\text { days }\end{array}$ & \\
\hline 10 & APBD to set as the local regulation & Max 31 Dec. & \\
\hline
\end{tabular}

As mentioned above, the draft of APBD from the executive is based on KUA-PPAS, which is expressed in a memorandum of understanding between the executive and the legislature. There is relatively no conflict in the formulation stage of KUA-PPAS. However, when KUA-PPAS is sent to the legislature, there may be debates and negotiations between the executive and the legislature (Yudhoyono 2003, 39). This situation of debate and negotiation will go on until the end of the process of making APBD. This conflict relates to the interests of legislators towards the base of their constituents or relates to the inconsistecy between RKPD and KUA-PPAS (Abdullah 2004). Here, the relation between the executive and the legislature can be seen as a principal-agent relationship (Johnson, 1994).

Legislators want to be elected again as legislators in the next election, bureaucrats want to maximize their budget, and constituents want to maximize their utilities. To be elected, legislators have to look for programs and projects that make them popular in the eyes of their constituents. This phenomenon, in the literature of public choice, is called the theory of political budget cycles (Rogoff 1990). This theory states that politicians, particularly the incumbents, are likely to direct government expenditure or fiscal policy to win them in the next election.

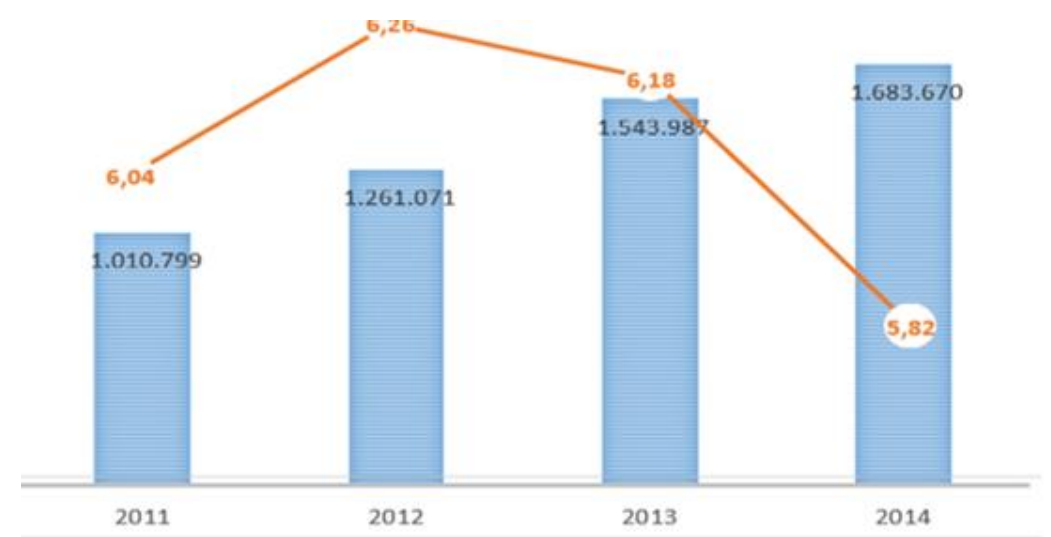

Source: The Local Government of Malang City (2015).

APBD (in rupiahs) and the Economic Growth (in \%) of Malang City

Figure 1

One of the result of those situation mentioned above, is the emergence of ghost budget (anggaran siluman), that is the budget that suddenly appears in APBD without going through the process of KUA-PPAS. For example, in 2014, BPKP (Badan Pengawasan Keuangan Pemerintah, the State Audit Agency) had found 
The Local Government Budget (APBD) and Its Inefficiency in the City of Malang, Indonesia

the ghost budget which reached 3,518 trillion rupiahs with 252 fictitious activities in the department of public infrastructure and 210,80 billion rupiahs with 58 fictitious activities in the department of health in the APBD of Jakarta Province (Kompas, November 6, 2014). In the City of Malang, as reported by Malang Post (on August 19, 2013), there were 40 billion rupiahs of the ghost budget in APBD of Malang City in 2013; whereas on July 10, 2015, Radar Malang reported 2.7 billion rupiahs in APBD of Malang City in 2015. The phenomenon of the ghost budget can be categorized as opportunistic behavior in the process of making APBD. The ghost budget can be understood as the unplanned budget, and it is the result of hidden compromises between the executive and the legislature. Because it is not planned, it is possible that the budget is not absorbed/spent, or in other words it becomes SiLPA (Sisa Lebih Penggunaan Anggaran, the Unspent Budget). Table 2 shows an overview of SiLPA in APBD of Malang City in the last five years.

Tabel 2 The Unspent Budget (SiLPA) of Malang City

\begin{tabular}{|l|l|r|c|}
\hline No & Fiscal Year & SiLPA (the Unspent Budget) & Increase (\%) \\
\hline 1 & 2010 & $67.571 .688 .021,77$ & 0 \\
\hline 2 & 2011 & $94.299 .406 .607,37$ & 139.55 \\
\hline 3 & 2012 & $161.443 .965 .225,79$ & 171.20 \\
\hline 4 & 2013 & $182.754 .567 .308,28$ & 113.19 \\
\hline 5 & 2014 & $322.985 .750 .377,67$ & 176.73 \\
\hline
\end{tabular}

Source: The Local Government of Malang City, 2015.

\section{CLOSING REMARKS}

This paper concludes that there is a strong relationship between the executive and the legislature in the process of making APBD in Indonesia. This relationship is principal-agent in nature, in which the legislature is acted as principal representing people as a whole while the executive as an agent representing its bureaucracy. It shows that there is an inefficiency in the process of making APBD. Because this budget is not well-planned, this budget finally becomes an inefficiency, in the form of the ghost budget, resulting from opportunistic behavior in the relationship between the legislature and the executive.

The ghost budget (anggaran siluman) is defined as the budget that suddenly appears in the final government budget (the final APBD) without going through the right procedure. The ghost budget can be understood as the unplanned budget, and it is the result of hidden compromises between the legislature and the executive. Because this budget is not well planned, it usually can not be executed, and then it becomes the unspent budget (SiLPA). This paper recommends to create more transparent system in the process of making APBD.

\section{REFERENCES}

[1] Abdullah, Syukriy (2004). "Perilaku Oportunistik Legislatif dalam Penganggaran Daerah: Pendekatan Principal-Agent Theory." Paper Presented in Inter-Nation Seminary in the University of Bengkulu, Bengkulu, 4-5 Oktober 2004.

[2] Baron, David P. and Ferejoho, John (1987). "Bargaining and Agenda Formation in Legislatures." American Economic Review. Vol. 77, No. 2, pp. 303-309.

[3] Bergman, Ulf Michael and Lane, Jane-Erik (1990). "Public Policy in a Principal-Agent Framework." Journal of Theoretical Politics, Vol. 2, No. 3, 1990, pp. 339-352.

[4] Gilardi, Fabrizio (2001). "Principal-Agent Models Go to Europe: Independent Regulatory Agencies as Ultimate Step of Delegation." Paper Presented at the ECPR General Conference, Canterbury (UK), 6-8 September 2001.

[5] Johnson, Cathy Marie (1994). The Dynamics of Conflict between Bureaucrats and Legislators. Armonk, New York: Sharpe.

[6] Mardiasmo (2002). Otonomi dan Manajemen Keuangan Daerah. Yogyakarta: Penerbit Andi.

[7] Maug, Ernst (2002). "Insider Trading Legislation and Corporate Governance." European Economic Review. No. 46, pp. 1569-1597.

[8] Rogoff, Kenneth (1990). "Equilibrium Political Budget Cycles." American Economic Review. Vol. 80. No. 1, pp. 21-36.

[9] Yudoyono, Bambang (2003). Otonomi Daerah: Desentralisasi dan Pengembangan SDM Aparatur Pemda dan Anggota DPRD. Jakarta: Pustaka Sinar Harapan. 